\title{
RECORD KEEPING IN NIGERIAN PRIMARY SCHOOLS
}

\author{
AISHA ZAID IBRAHIM (Mrs.)
}

\begin{abstract}
Record keeping is a vital responsibility of the school administrators because of the indispensable roles it plays in the effective day-to-day running of the schools. Keeping of records in primary schools is often organized around the life cycle of creation, storage, retrieval, retention and disposition which is concerned with protecting them. The paper attempts to examine various records kept in primary schools. Importance of record keeping, maintenance, storage and retrieval for effective decision making in the administration of primary schools policies have been discussed. The paper recommends that there is the need for training and re-training of primary school administrators like headmasters and teachers on the importance of record keeping.
\end{abstract}

\section{Introduction}

Over the years, primary schools administrators had paid lip-services to the proper keeping of records. All that schools do is simply teach and graduate pupils. However, it has been observed that records keeping in Nigerian primary schools are poorly practiced. Records can be seen mutilated, torn, exaggerated and misplaced (Akanbi, 1999). It is imperative for a school to keep records to serve as accurate information to help in assessing meaningful progress of the school. Records must be complete and be made available when the need arises. Records which are not regularly kept will be incomplete and misleading. Badly kept records can hinder the progress of the school. The school head must see that records are devoid of exaggerated reports or false statements. Schools records that contain untrue statements are worthless and show the type of personality the keeper has. A primary school head is expected to keep records which are required by law and some others, which are also helpful.

\section{School Records}

A record, according to UNESCO (1991) is a document proof of a transaction. It can refer to any activity which falls within the necessary normal school activities. Schools are charged with the responsibilities of teaching and providing the conducive environment/or learning. In the discharge of these functions, many activities are involved. These include admission of pupils, employment of teaching and non-teaching staff, procurement and use of materials as well as collecting and disbursement of funds. A record is therefore any written document where the activities of the schools are written (NTI, 2008: 108). Records are regarded as information handed down or preserved. Peretomode (1998) sees school records as all kinds of books and files or other documents containing information relating to what goes on in the schools, and what types of property the school owns. Aleiyideino (2002) also defined record as a written statement about a happening. School record keeping according to him contains information about the school that will enable the authority to take decisions and assess the progress of the school.

Going by various definitions, it can be deduced that, school record keeping referred to the history of the school kept systematically. This means that the systematic growth of the 
school at various time need to be thoroughly recorded and kept by the school administrators. It is the authentic register of instruments of official accounts of transaction or occurrence which are preserved (Olanrewaju, 2008). Record keeping is a vital responsibility of the school administrator because of the indispensable role it plays in the effective day-to-day running of primary schools.

School administrators rely on information that is captured in records. Keeping of records is often organized around the life-cycle that all Records follow; (i) creation, (ii) storage, (iii) retrieval (when need arises), (iv) retention and (v) disposition, which include protecting all vital records.

\section{Qualities of a Good Record}

A good record must possess the following attributes:

i. $\quad$ should provide easy storage and retrieval ;

ii. should be easy to understand/interpret based on common knowledge;

iii. Should be easy to locate and available for reference at any time;

iv. Should give detailed or complete information about the events/ activities;

v. Should be able to generate further information; and

iv. Should be used to take appropriate action on what it is collected (Bello,2010).

\section{Legal Implications of Keeping Records in Primary Schools}

There are various education laws/edicts on record keeping in schools. According to Olagboye (2004) Education Law in virtually all state of the federation requires that every school must keep certain specified records. For example Section 22(1) of the Education (General) Regulations 1964 of Education Law, 1964, of former Northern Nigeria stipulated that every institution, 'other than a correspondence college or training college' shall keep certain 'records and books'. Section 24 of the same regulations spelt out the penalties for non compliance with Section 22(1) (GNN, 1964). Below is some of the legal basis for keeping records in Nigerian primary schools

(i) Education law demands that certain school records should be kept in school, if such records are not kept by school, the school is operating against the education law.

(ii) Every child in the school has the legal right to have his personal records in the school as a mark of having passed out or having attended that school,

(iii) The Federal Republic of Nigeria's constitution stated that school record keeping is one of the multi various activities of primary schools, therefore it has to be maintained,

(iv) Pupils' academic record must be completed and kept thoroughly. Any detected mistakes can be taken up by the pupils and the law courts provide a good arbiter for such pupils and their parents to seek for justice,

(v) Keeping of school records, such as attendance register can save the school from the law of liability. The law of liability connotes that the school can be held liable for any injury sustained, inflicted or otherwise experienced by the learner during the school hours,

(vi) Proper record keeping in schools help in challenging cases of forged certificates by learners or schools before the law courts. 
(vii) It is mandatory for teachers and headmasters to have copies of the current National Policy of Education with them. This is to ensure that teachers have documents they can refer to from time to time which will guide them since ignorance cannot be claimed as an excuse in law (Ojelele, 1998).

\section{Classification of School Records}

According to Agunwa (1986), school records are divided into statutory and non-statutory. Ojerinde and Tukur (2005:21) classified school records into (a) statutory records (b) academic records, (c) finance records, (d) staff record and (e) general records. It is in light of the above that different school records are going to be discussed.

\section{Statutory and Non-statutory School Records}

The statutory school records are the records that are mandatory by law to be kept in primary schools for effective school administration. These include the records to be kept in headmaster's office and those that are kept by classmaster's. While, non-statutory records are those records that are not mandatory by law but, they are vital or essential to headmasters in running the schools effectively.

\section{Records Kept by Class Teachers}

According to Agunwa (1986) the records to be kept by class teachers are as follows'

(i) Class attendance register

(ii) Syllabus and scheme of work

(iii) School record of work or weekly diary

(iv) Time-table

(v) Continuous assessment book

\section{Class Attendance Register}

Class attendance register shows the daily record of attendance in each class in the school. The names of pupils are written in alphabetical order, surname first and in block letters. Male names are written first in blue or black ink, while female names are written next and in red ink. The new trend is to write the name of all the pupils in blue or black ink and the absentees in red ink. It is kept by the class teacher or master and the attendance must be marked by him (and not by the prefect of the class except so delegated if the teacher is not around). The register is marked twice in a day, at the beginning of the morning session and at the beginning of the afternoon session. Class Attendance Register is marked by indicating the presence of each pupil with a slanting stroke to the left in the morning and to the right in the afternoon ( ()$(/)$. The absence is shown with a naught in the appropriate columns (o). At the end of every term, the class teacher ought to close the register and submit to the headmaster to cross check and sign as correct record.

The following particulars are embodied in the class attendance register; fees paid if any, pupil's name, the number in the admission register, age, date of admission, date of promotion to the class. The weeks of each term are depicted by recording the day on each week ends, in cases where the school weekends at midweek, like for example, a primary school summary of attendance is checked on Wednesday and entered at the bottom of registers sheet for each session, and at the right hand side under weekly totals for each 
pupils' attendance for the week. For both, the weekly totals must correspond with the percentage attendance. The percentage attendance is worked out as total attendance $\mathrm{x} 100$ all over expected attendance. For example, in a class of 40 , for normal week of 10 sessions the percentage attendance becomes

\section{Total attendance $\times 100$ $40 \times 10$}

On the other hand, for an interrupted week of 6 sessions (or 2 days) only, the \% attendance becomes

\section{$\underline{\text { Total attendance } \mathrm{x} 100}$ \\ $40 \times 6$}

This percentage attendance gives the teacher, headmaster or visitors a picture of the level of absenteeism or regularity of attendance in the class. (At the end of every the class teachers ought to close the register and submit to the headmaster to crosscheck and sign as correct record (Olagboye, 2004).

\section{Syllabus and Scheme of Work}

The syllabus is a comprehensive collection of all the subjects taught in the school. It shows the course contents to be covered in each subject area in the various classes. It is from this record the teacher draws his scheme of work. Ozigi (1977) describes the scheme of work as a book showing the plan of work to be covered by each class within the term or session. The scheme of work which breaks down the syllabus into teaching units should be drawn up before the school year begins.

\section{Record of Work and Diary}

The school diary (also referred to as teachers' record of work) shows the work done in each term for each class in the school. Provisions are made in it to record the work covered in each subject by the class every week. This guides a new teacher to the class to know where to start from. Usually, the entry is made by the subject teacher who also signs it. This record is submitted to the headmaster or subject head at the end of every week for marking and signing. This record helps to check laxity in the school work and on the teachers. It also aids teaching by helping in directing teachers on what to do and ensuring continuity.

\section{Lesson Note/Plan}

The lesson note guides the teacher in his teaching. It is written on daily basis or weekly. It is developed from scheme of work or unit plan. It is passed from to the headmaster to head of Department for signing before it can be used by the subject teacher. The writing of a lesson note ensures that the teacher has given serious thought to the subject before hand, has studied all relevant materials and with a clear knowledge of the level of readiness of his pupils. Agunwa (1986) and Peretomode (1998) highlighted the following procedures in lesson preparation.

(i) subject to be taught and topic 
(ii) behavioural objectives

(iii) entry behaviour or previous knowledge

(iv) teaching aids or materials

(iv) step by step procedure (the body of knowledge to be imparted or skill to be practiced)

(v) evaluation

(viii) summary

(ix) conclusion

\section{Time Table}

A school time table can be described as a plan or chart on which the subjects of the Curriculum has been distributed over the teaching periods of the school day and days of the week. The time-table ensures that no subject receives undue attention at the expense of the others and that none is totally neglected. A good time-table according, to Farrant (1981), takes care of a number of factors. These include:

(i) The minimum number of hours of instruction prescribed by law must be met.

(ii) Intervals or breaks are provided for relaxation or recreation.

(iii) The duration of the lesson are made to suit the age and span of concentration of the pupils.

(iv) Periods are chosen to suit the demand of each subject. For the primary schools, it has been the practice of the experts in the State Universal Basic Education Boards to prepare a standard time table for the lower and upper primary classes, and distribute them to the primary schools. The teachers have to follow the time table strictly, only making minor alterations when circumstances demand. The more confidence that the authority has in the headmaster and staff, the more freedom they give them in drawing up their school time table.

\section{Continuous Assessment Book/Terminal Report Card}

This is a continuous record or a combination of records, which contains comprehensive information about each pupil and which provides a summary of the pupils academic pursuit in the school. It includes information such as family background, social activities and interest, date of admission, grades obtained in each course, attendance records, height, weight, and general health status of the pupils. In fact, it can be referred to the pupils' permanent record or simply as the pupil's individual record card (Pretemode, 1998). The cumulative record helps the school head to give a history of a pupil in the school at a glance. It could therefore be said that this record is the most important record of the pupils in the school system.

\section{Terminal Report Sheet}

This is almost same with the cumulative record, but this shows the academic performance of the pupils in each subject, his position in class, comments by the class teacher, and headmaster. 


\section{Statutory Record Kept by Headmaster}

This includes all the records that are required by law to be kept in the primary school Headmaster's office. These are:

(i) Admission register

(ii) Log book

(iii) Visitors book

(iv) Cash record book

(iv) Corporal punishment book

(v) Counterfoils of transfer and leaving certificates

(vi) Minutes book of the Board of Governors

\section{Admission Register}

Admission register is a register containing list of all admitted pupils of the school. It shows the record of the admitted pupils with admission number, and anybody who is not registered in the register and given admission cannot claim to belong to the said school. Qualification for membership of the old boys (or old girls) association of the school can be verified from the admission register. This register also shows the names of all the pupils enrolled each year from the first year of the establishment of the school into the school, whether as a new entrance into class 1, data on the progress of each pupil and withdrawal of pupils, data on the previous schools attended if any, the pupils assigned admission number, the sex, name*, home address, and reasons for withdrawal from former school to the latter, where applicable.

\section{Log Book}

The log book can be described as a book of jottings for the history of the school which could be compiled during jubilee celebrations. It is a record of all significant events in the life of the school, especially those events that constitute a land mark. For example; introduction of a new syllabus, change of leadership of the school, a fire disaster, death, date of opening and closing of school terms and so on. The headmaster has to keep this book under lock and key.

\section{Visitors Book}

This record book is open to important visitors to the school. The purpose of the visit should be recorded. The names, addresses and the dates of the visit are recorded in the visitor's book. The visitor's book usually contains pleasant and unpleasant comments because visitors are often given the opportunity to summarize their impression of the school at the time of their visit in the visitor's book.

\section{Cash Record Book}

This shows every item of receipt and expenditure which is kept by the accounts clerk where they do exist. The cash record book is kept in primary schools to determine the income and expenditure profile of the school. This record is help to promote accountability, transparency and fiscal discipline. 


\section{Corporal Punishment Book}

The word corporal is a Latin word meaning that type of punishment that inflicts pain on the human body e.g. canning, beating. It is the record of major punishment kept to protect the pupils from arbitrary punishment from teachers and exonerate teachers from fabricated reports of the punishment by pupils (Peretemode, 1998). The headmaster should approve the punishment to be given. The record should show the name of the pupil being punished, the teacher or person administering the punishment, the nature of the punishment and date. This type of punishment should be administered by the headmaster or his delegates such as discipline master and on the assembly ground before the entire pupils and teachers, to serve as lesson to others. The record is now called character correction book (NTI, 2008).

\section{Inventory or Stock Book}

This shows Record of supply of equipment and other materials to school. It is divided into two parts, one part showing the consumable items and the other part showing the nonconsumable items. The consumable stock covers the supply of articles such as chalk, duster, diaries, registers, biros, and other types of stationary constantly in use in the school. Non-consumable items include those things like furniture, projectors, television, tape-recorders, games equipment and so on (Farrant, 1981). The stock book helps the school head to know the vital supplies that are running out and can therefore ask for replacement of the stock from the appropriate school board.

\section{Reference Books}

The reference books include the current education laws and policies, teachers service manual containing the service conditions of teachers in Nigeria (Federal, state and local government areas); financial instructions; regulations and circulars on policy matters; current syllabus and transfer certificate booklets and files (NTI, 2008 ).

\section{Counterfoils of Transfer and Leaving Certificate}

The transfer and leaving certificates are two separate school records which Section 29 of the Education (General) Regulations 1964 of Northern Nigeria enjoins all school to keep. The transfer and leaving certificates are usually printed in duplicate and numbered serially in the form approved by the state ministry of education or the Local Government Education Authorities and distributed to schools. The certificates are normally issued free to the pupils who wish to leave one school on transfer to another or completed full primary education and on demand from the parent/guardians. It is issued and signed by the school headmaster (Olagboye, 2004). It is instructed to note that primary school leaving certificate is no more in existence. The children are expected to transit automatically to junior secondary school to complete their nine- year basic education (Federal Ministry of Education, 2013).

\section{Non-statutory School Records}

These include staff attendance register; staff movement book; headmasters desk diary; Staff meeting minutes book; duty assignment register; files and float; garden and farm record/extra-curricular; health record book; hygiene inspection; and boarding records. 


\section{.Staff Attendance Register}

This is the record that shows punctuality and regularity of the teachers. It is always kept either in the headmasters office or in a place where every teacher will see it, write his/her name, the time of arrival and append his/her signature. Teachers also sign off at the end of school day. The headmaster or his assistant checks the time book at the end of the school day and enters his remarks. He is expected also to rule off as soon as assembly ends. Those who come later can sign under the line. While the absentees are marked absent at the last page of the time book (Agunwa, 1986).

\section{Staff Movement Book}

This shows the movement of teachers in the school, either leaving for hospital or going to bank and so on. It shows time of leaving, destination, time of returning back and signature. It is usually kept in Headmasters office.

\section{Headmasters Desk Diary}

This is the diary in everyday use by chief executives as well as private individuals apart from vital information like public holidays, postal rates, distances, popular hotels in different towns; it is also used to keep appointments. All these are very vital to the administration of school, so also to the daily life of the headmaster.

\section{Staff Meeting Minutes Book}

This shows the decisions reached in meetings. A member of staff who is appointed as secretary usually takes down the proceedings of meetings. The staff minutes should indicate the date of the meeting, venue of the meeting/ and list of the staff present and absent.

\section{Duty Assignment Register}

It is the work of the headmaster from time to time to assign duties to his staff. This is done at two levels, on permanent or semi permanent basis and on temporary or ad-hoc basis. This shows the teacher who is responsible for specific duty; it could be daily duty master who is to conduct morning assembly, sanitation and general school daily activities. The roasters must be prepared in advance and placed both on general notice board and on the staff notice board inside the staffroom. The original copy should be displayed on the headmasters' office notice board, so that as soon as he notices any lapses, he knows who should be held responsible.

\section{Files}

The headmaster must keep several files for all the official correspondences connected with the school. Files must be opened to cater for all the school official correspondences e.g.; circulars from the state NUT; confidential reports; general circulars from the state UBE board etc. 


\section{Garden and Farm Record/Clubs and Societies}

This record is to be kept by senior agricultural master, whose training includes the proper keeping of this record. The record is kept to be used by teachers and pupils not merely to be shown to inspection. Clubs and societies records, on the other hand, are the record showing club, societies and organizations to which pupils belong e.g.; Boys Bridge, Girls Guide, Boys Scout, Man 'O' War, Literary and debating society etc.

\section{Health Record Book}

This is the record that shows the names of pupils who were sick and was sent to local dispensary or hospital for treatment and the nature of the illness and the treatment given to them.

\section{Hygiene Inspection}

This shows the record of hygiene inspection results". Inspection scores are done on a rough sheet before the final result is transferred to the permanent record.

\section{Boarding Records}

Boarding records are divided into boarding regulations and daily routine. Boarding regulations cover such areas as exit, custody of pocket money, visits to staff quarters, strolling beyond school bounds, free days, visitors etc. They should be reviewed from time to time in socio-economic development. The daily routines enable pupils in the boarding house to manage the time at their disposal. Both the boarding regulations and the daily routine enable pupils to form proper habits and adopt life patterns that may lead them throughout life.

\section{Reward Book}

The reward book is kept in some schools, but it is actually a record that should be kept in all the primary schools, for it helps to identify pupils with special talents gift and pupils' contributions that promote the good image of the school (NTI,2008).

\section{Testimonial}

The testimonial record is an academic document that is usually given out to final year pupils or pupils transferring from one school to another. The testimonial refers to attestation of pupils' learning ability and performance, pupils' enrolment at school and the pupils' character and hobbies.

\section{Examination Records}

The examination record is one of the most important non-statutory records kept in primary school. The record contains items such as performance of pupils in examination, achievement and continuous assessment tests, and significant questions from past examination. 


\section{Importance of Record Keeping in Primary Schools}

Keeping of school records is one of the most important aspects of school administration.

The following serves as the importance of keeping records in primary schools.

(i) School records provide useful information to an employer of labor who may want to recruit pupils for jobs.

(ii) They help the higher institutions of learning who may seek information about pupils' academic achievements.

(iii) They provide parents with the true picture of their children's behavior and general performance in school

(iv) They help the inspectors in assessing the performance of pupils and teachers objectively, and to offer advice and make concrete proposals or suggestions for improvement.

(v) They help the headmasters in providing figures about staff and pupils for the purpose of an objective appraisal of performances in the school and to buttress his request for staff and facilities.

\section{Advantages of good record keeping in primary school}

The advantages of keeping records in primary school and their retrieval school administration cannot be over emphasized. Farrant, (1981), highlighted the advantages of good record keeping in primary schools as follows:

(i) School records serve as information bank from which the school administrators and the staff can recall or restore information,

(ii) Through the use of school time-table it could be argued that school records help in the co-ordination of school activities.

(iii) School records help to show important events that took place in the school, within the session as often shown in the use of the log book and visitors' book.

(iv) School record/help to ensure accountability in the school. For example, the cash book and stock book show the income and expenditure and stock in the school respectively. These books are made available to the auditors.

(v) School records help the headmaster in decision-making. They provide the school head with the raw materials to make objective and rational decision on issues of teachers and pupils' discipline, promotion and teaching and learning.

(vi) Accurate and comprehensive record keeping helps to facilitate the movement of children from one school to the other as data contained in the records on the pupils will help both the pupils, teachers and school head of the new school.

(vii) Record keeping enables educational planners to identify areas of need that should be accorded priority. Records, therefore, facilitate the work of educational planners specially in the improvement of the curriculum.

(viii) Record keeping enhances experimentation and encourages research in education.

(ix) School records can be used by school personnel as evidence in a court of law. Records are the decider, is the pillar of "wisdom" that a man is innocent, wrong or right is based upon available evidence.

Records when properly preserved make everyone to become cautious and to act within the framework of the school system. For instance, school records help the school head in 
discussing issues connected with government policies with facts and figures, with staff, pupils, parents, board officials, LGEAs

\section{Disadvantages of poor record keeping}

It has been stated earlier on that record keeping is vital to the smooth running of our school system. But, for such records to be useful to the school administrator or others, it must be complete, objective, factual or truthful and must be bearable or accessible to the person who needs them. Poor record keeping habits, however, may militate against the positive role that records play in the day to day running of a school. There are number of disadvantages of poor record keeping in primary schools. These include:

(i) Poor record keeping may affect efficiency in decision-making and consequently the effective administration of school.

(ii) The academic progress of a school may be hampered if syllabus and scheme of work cannot be covered, because, lessons are repeatedly taught due to lack of records of work done to serve as a guide to a new teacher.

(iii) The absence of accurate records on pupils and teachers will make it difficult for education personnel to objectively appraise the competence and usefulness of teachers and the performance of pupils in the school system.

(iv) Poor record keeping or lack of it increases administrative inconveniences and legal entanglement.

(v) It could affect the welfare of staff for instance, where school records are not carefully kept hand over between incoming and outgoing school personnel or head becomes difficult and trouble prone, just as a missing file of a teacher in the school board may delay his appointment, promotion, increment or payment of his benefits e.g. gratuity/pension.

(vi) Lack of records or improperly kept records may make difficult the much needed continuity in the running of our school system.

\section{Maintenance of School Records}

According to Farrant (1981), the maintenance of school records is the sole responsibility of the school administrator. The maintenance of school records involves all the activities that ensure they are in good conditions (E.g. not worn out or torn, that they are legible) and kept in an orderly state.

(i) Filing in cabinets and use of drawers and shelves where filling cabinets are not available, to prevent them from termites, insects and rates. Insecticide can also be applied in the process.

(ii) Avoiding mutilations of the records

(iii) Ensuring that record, that are top secrets are kept secret.

(iv) Proper/careful arrangement of the record books in shelves and cabinets,

(iv) Periodical cleaning/dusting of the record books in shelves to prevent them from being damaged by termites, insects and rats,

(v) Record can be maintained by lamination

\section{Storage and Retrieval of School Records}

There are basically two methods of storing and retrieving records in schools. These methods are manual and electronic: 
(1) Manual storage system involves keeping school records in written form in the following formats:

(i) files

(ii) shelves/cupboard

(iii) cabinets/drawers

In this method information on pupils and other school personnel, such as teachers and non-teaching staff, school facilities and programmes can be written or graphically presented on paper such as books, reports, ledgers etc and kept in the headmaster's office.

(2) Electronic storage system involves the use of electronic devices in storing school data either in written or graphic form. They have very large memories for storing information such devices include:

(i) handsets

(ii) personal computers (desktops, laptops, notebooks, palmtops etc)

(iii) Microfilms.

Handsets can be programmed to store important information on school personnel and events, and set to reminder. The new blackberry handsets are designed to help executives plan. Computer hard disc has very large memory for storing data. Likewise removable memories, such as diskette (almost obsolete), compact disc (CD) and flash drives can be used as backups to store relevant data for future use. Microfilms can be used in storing important events and school activities, such as tapes/films for future viewing projection/(Bello, 2010).

Retrieval follows the same pattern as the storage system it could be manual or electronic.

Manually stored data are retrieved from files, cabinets and shelves by going through the papers filed either alphabetically or numerically. Electronically stored data are retrieved by logging into the system to open the document. The data are then viewed/accessed, used and saved back or deleted as required. The information could be printed out on paper. Recorded tapes can be viewed or projected using appropriate projector.

\section{Stages Involved in Using Computers for Storage and Retrieval of Records}

NTI (2008) highlighted seven stages involved in using computers for storage and retrieval of records, these are:

\section{Data Collation}

Raw data are normally collected for the federal, state and local government agencies that are responsible for primary education by the headmasters through teachers on pupil's enrolment, material resources, finances and other infrastructure. Data collection at the classroom level is the first stage in the overall national data collection exercise, then followed by the school level collection. Such data include enrollment per class and for the whole school which can also be classified on gender. The next stage is the collation at LGEA level; once this is correct and complete, this then guarantees the collation at the national level. When this entry is made into the education data bank then problems associated with data in Nigeria will be a thing of the past 


\section{Data processing}

With computers, all data collected and collated will be processed using the computers electronic software. This saves more time than the manual processing.

\section{Data Analysis}

Raw data are fed into the computer system and depending on the nature of the problem to be solved, a programme (software) exists in the computer that sorts and analyses the data presented and eventually processes it in the desired form.

\section{Data storage}

Data processed and analyzed can be stored in the computer for future reference or processing. There are so many media for storing data in the storage outside the main memory through:

(i) the use of back up storage'

(ii) storage on the main memory through the user of floppy diskettes. CDROM, Microfilms, Optical disk, Magnetic disks and so on.

\section{Data Retrieval}

Stored items or data on the computer can be accessed. This is done by querying the computer, which responds to the query by displaying solutions to the subject rose. The querying vary from one to the other.

\section{Data Usage}

The end product of data collection, collation, processing and storage is to make effective use of the data collected for decision making in schools.

\section{Conclusion}

Records can only be meaningful and useful when they a properly kept and updated at the right time. Updating records keeps them alive and ready for retrieval and use when the need arises. Good keeping of records and maintenance can positively affect the effective administration of primary schools. It can, for example, bring about proper coordination of school programmes and activities, control and discipline, guidance and counseling of pupils and teachers and also give direction in the planning programme and activities. Therefore, the headmasters and teachers must make sure that all relevant information are provided in all records at appropriate time so that anybody seeking information can find them readily available.

\section{Recommendations}

Going by the discussions regarding record keeping in primary schools, the paper recommended that: 
(i) The Federal, State, Local Governments and all stakeholders in primary school education should ensure that all records that are mandatory by law and those that are vital for effective day-to-day running of school/are properly kept and maintained for easy retrieval when need arises.

(ii) There is also the need for the training and retraining of primary school administrators and teachers on the importance of proper records keeping. 


\section{References}

Agumva, C. O. (1986). School Records for Effective Administration. Enugu: Mentina Press Limited.

Aleiyideino, S. C. (2002). Record keeping in school m:nagement :Course Book on Education Kaduna: NTI, Press.

Bello, A. N. (2010). Record keeping in schools. Taraba: Gurara press.

Farrant, J. S. (1981). Principles and Practice of Education. London: Morrison and Gibb, Edinburgh, Limited.

Federal Ministry of Education (2013). National policy on education. Yaba, Lagos: NERDC Press.

National Teachers Institute (NTI) (2008). Improvization of Instructional Materials. Kaduna: N T I, Press

Ojelele, P. K. (1998). Legal Basis for School Record Keeping in Nigeria. In Olagboye, A. A. \& Fadipe, J. O. (Eds.). Management of Nigeria Education in Law, Structures and Responsibilities. Ondo: NIEPA.

Ojerinde, D. O. \& Tukur, H (2005). Record keeping and Inspection in schools. Kaduna: NTI, Press.

Olanrewaju, I. T. (2008). "Importance of Record keeping in schools". A Seminar paper presented at the Departmental seminar presentation, Department of PHE, University of Ilorin.

Olagboye, A. A (2004). Introduction to Educational Management in Nigeria's. Ibadan: Daily Graphics Limited, Nigeria.

Ozigi, A. O. (1977). A handbook on school administration and management. London: Macmillan.

Peretemode, V. F. (1998). Introduction to Educational Administration, Planning and Supervision. Maryland, Lagos: Joja Press Limited.

UNESCO (1991). Managing Records at School Level, School Record: The Zimbabwean Experience. 